\title{
Life-Cycle Assessment of Crude Palm Oil Produced at Mill J, PT XYZ, Sumatera Island using Eco-indicator 99
}

\author{
Pertiwi Andarani ${ }^{1, \mathrm{a}}$, Winardi Dwi Nugraha ${ }^{1}$, Desinta Sawitri ${ }^{1}$, and Wiwik Budiawan ${ }^{2}$ \\ ${ }^{1}$ Dept. of Environmental Engineering, Faculty of Engineering, Diponegoro University, Indonesia \\ ${ }^{2}$ Dept. of Industrial Engineering, Faculty of Engineering, Diponegoro University, Indonesia
}

\begin{abstract}
The Crude Palm Oil industry has now become the largest agricultural industry in Indonesia. Nevertheless, the growth of CPO industry could also bring negative impacts on the environment if the company does not control their emissions and discharges properly. Life-cycle Assessment (LCA) is one of the tools that can assess the environmental impacts due to CPO production activities. This study aims to assess the potential environmental impacts arising from the CPO production system at Mill $\mathrm{J}$, PT XYZ, Sumatera Island by using Eco-indicator 99. Based on this study, in 2015, the process in plantation and mill contributed to climate change category was 0.013 DALY or after normalized $202 \mathrm{Pt}$. Meanwhile, the land use category has $395 \mathrm{PDF}^{*} \mathrm{~m}^{2} \mathrm{yr}$ or $30.8 \mathrm{Pt}$. Meanwhile, all of the other categories were less than $30.8 \mathrm{Pt}$, hence, the highest impact of this CPO production system is climate change at the activities in industrial estate (fertilizers usage) and industry (emitted from waste water of palm oil mill).
\end{abstract}

\section{Introduction}

Some countries in Southeast Asia such as Indonesia, Malaysia, and Thailand become the largest producers of $\mathrm{CPO}$ in the world. The $\mathrm{CPO}$ and its derivatives production in Indonesia were 32.5 million tons in 2015 [1]. Meanwhile, palm oil plantation area reached 9 million hectares [1]. Various products can be derived from CPO such as food, cosmetics, biofuels, and other commodities. Palm oil grows in tropical climates and becomes the competitor of tropical rain forest. However, further expansion of palm oil plantation should consider the environmental impacts arise from anthropogenic activities.

The environmental impacts of palm oil production system are from not only the plantation, but also the palm oil mill. Palm oil mill discharges waste water and solid waste. If those wastes are not properly managed, potential environmental pollution could not be prevented. In order to identify and assess the environmental impacts of a product, a method widely used is life-cycle assessment (LCA). CPO production system from cradle-to-gate consists of nursery, palm oil plantation or estate, palm oil mills, water treatment plant, waste

a Corresponding author: andarani@ft.undip.ac.id 
water treatment plant, boiler, etc. The impacts are varied based on the production system used, such as carcinogenic, respiratory organics, respiratory inorganic, climate change, radiation, ozone layer, ecotoxicity, acidification/eutrophication, land-use, minerals and fossil fuel uses.

Some studies related to LCA of CPO have been conducted worldwide. Depend on the scope, objective, location, and the production system, the results of studies could be varied. The largest impact of CPO production in Indonesia is climate change [2,3]. CPO-based biodiesel also has 66\% larger environmental impact than Jatropha-based CPO according to assessment by using Simapro Software [4].

PT XYZ has several palm oil mills in Sumatera and Kalimantan Island. One of the mills located in Sumatera Island is Mill J. The Mill $\mathrm{J}$ is well known for its development on composting process. The solid waste has been treated, but further improvement needs to be planned. Cleaner production is an option to improve the production system to minimize the environmental impacts. Therefore, as the first step, this study aims to assess the environmental impacts from the CPO production system at Mill J. LCA can be used to achieve this objective. The Simapro Software has been known for its reliability to calculate environmental impacts based on the product's life-cycle.

\section{Methods}

\subsection{Crude Palm Oil Production System at Mill J}

The activities in Mill $\mathrm{J}$ were done in oil palm estate (plantation) and palm oil mill. The area of estate is approximately $203 \mathrm{Ha}$. There are two kinds of planting-year, i.e. in 1993 and 1995. Replanting will be conducted after the existing plants reach 25 years old. The operation in this estate includes harvesting, herbicides and fertilizer application, land application (come from palm oil mill effluent), and pest control. In the palm oil mill, fresh fruit bunches (FFB) are processed to become CPO. The other supporting system of this production includes water treating plant (WTP), waste water pond, boiler, and composting. The by-product of this CPO production system is palm kernel that will be transported to palm kernel oil mill.

\subsection{Scope}

In this LCA study, cradle-to-gate principle has been used to assess the environmental impacts of the CPO production system at Mill J. The system boundary of the selected production system can be seen in Fig.1. In this system, there are two stages, i.e. background stage and foreground stage. The background stage is the process indirectly related to the system. The input both energy and materials will affect the environmental impacts of the product. Meanwhile, the foreground stage is the process directly related to the production system. This includes all of the process starting from the oil palm plantation (the output is FFB) until the product (CPO) transported to CPO storage. This also includes waste, such as empty fruit bunches (EFB), shell, fiber, and palm oil mill effluent (POME). The by-product of this system (Kernel) is out of this study scope. 


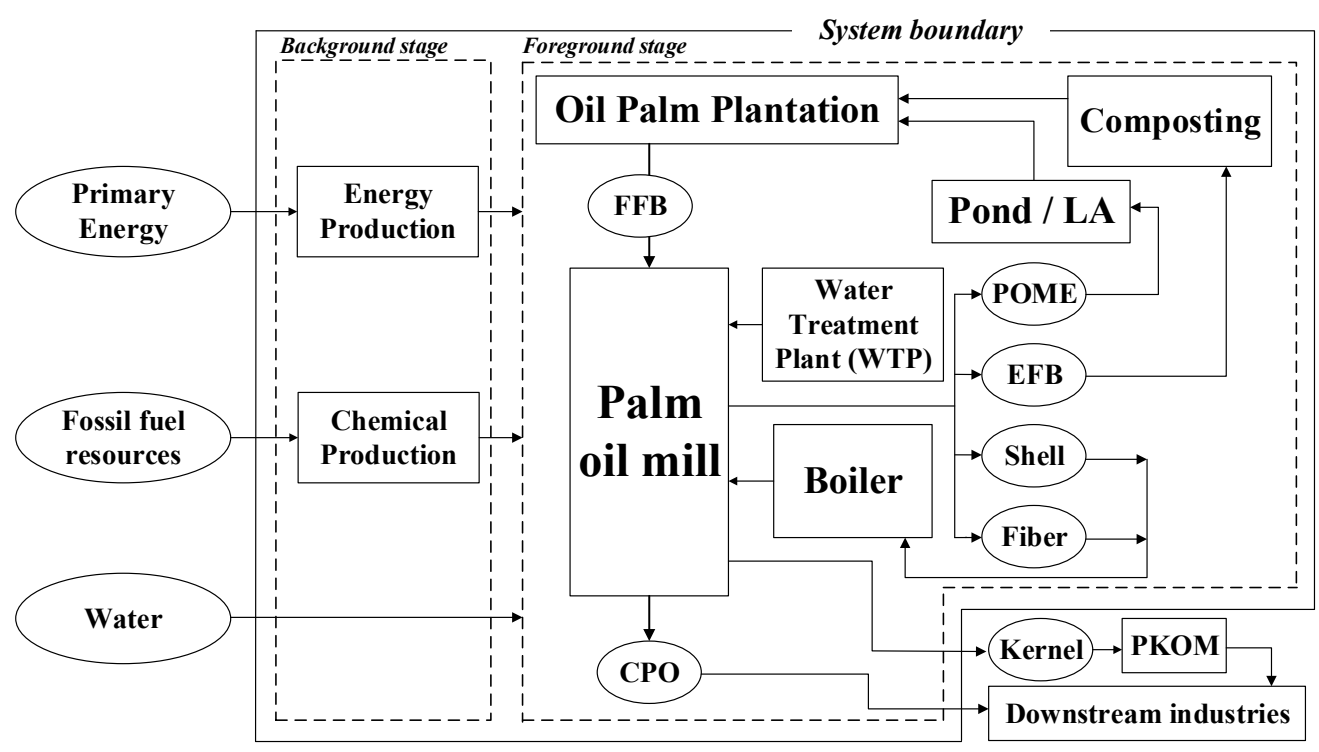

Fig. 1. System boundary of CPO production system at Mill J. CPO: Crude Palm Oil; POME: Palm Oil Mill Effluent; EFB:Empty Fruit Bunch; PKOM: Palm Kernel Oil Mill; LA: Land Application

\subsection{Simapro v.7.1}

The Simapro v.7.1 has been used to assess the environmental impacts of this CPO production system. Eco-Indicator 99 was selected as the life-cycle impact method because of ISO 14040 recommendation. All of the relevant process and affecting the environment was inputted to the scope of this study. The impacts of transportation of all chemical agents such as fertilizer and herbicides were not included in this study, as well as the human aspect.

\section{RESULTS AND DISCUSSION}

\subsection{Life-Cycle Inventory (LCl)}

Inventory Data is collected based on direct observation in the field, as well as data from estate and mill. In addition to the main product (CPO), other outputs from the production process are POME, EFB, fiber, and shell. The generated POME will be forwarded to the waste water pond, and flow to the plantation area as a liquid fertilizer or land application. Fiber and shell are the fuel source of the boiler in the plant to produce steam. EFB will be processed into compost that will substitute the use of chemical fertilizers. The average FFB produced per hectare is about 30 tons FFB / ha / year. Data of the chemical agents as well as the fuels used in the system has been collected and depicted in Table 1 . The production capacity of the palm oil mill is 30 tons/hour. In the process, it takes a variety of inputs ranging from materials, energy, transport, and so forth. In Table 1, there are some data from the Mill J needed in this study. All of these data were inputted into SimaPro software. 
Table 1. Plantation and Mill Data for input.

\begin{tabular}{|c|c|c|c|}
\hline Parameter & 2015 & Parameter & 2015 \\
\hline \multirow{6}{*}{$\begin{array}{l}\text { Fertilizer } \\
-\mathrm{N} \\
-\mathrm{P} 205 \\
-\mathrm{K}_{2} \mathrm{O} \\
-\mathrm{MgO} \\
-\mathrm{B}_{2} \mathrm{O}_{3} \\
\end{array}$} & \multirow{6}{*}{$\begin{array}{l}0.828 \text { ton } \\
44.112 \text { tons } \\
99.69 \text { tons } \\
3.839 \text { tons } \\
6.025 \text { tons } \\
\end{array}$} & FFB processed & 102,537 tons \\
\hline & & Electricity from genset & $366.56 \mathrm{MWh}$ \\
\hline & & Electricity from steam turbin & 2,077.96 MWh \\
\hline & & Diesel fuel for mill & 154,452 liters \\
\hline & & Shell & 5,306 tons \\
\hline & & Fibre & 11,535 tons \\
\hline Compost & $1,552,180 \mathrm{~kg}$ & Empty Fruit Bunch (EFB) & 21,533 tons \\
\hline LA & $120,236 \mathrm{~m}^{3}$ & Water usage & $148.123,95 \mathrm{~m}^{3}$ \\
\hline $\begin{array}{l}\text { Herbicide } \\
\text { - Glyphosate } \\
\text { - Metsulfuron Methyl } \\
\text { - Paraquat Dichloride } \\
\text { - Triclopyr Butoxy } \\
\end{array}$ & $\begin{array}{l}348.63 \mathrm{~kg} \\
8.308 \mathrm{~kg} \\
46.368 \mathrm{~kg} \\
17.433 \mathrm{~kg} \\
\end{array}$ & $\begin{array}{l}\text { Chemical agent } \\
\text { - } \mathrm{CaCO}_{3} \\
\text { - Soda Ash } \\
\text { - Alum } \\
\text { - B } 120+\end{array}$ & $\begin{array}{l}162.800 \text { tons } \\
19.464 \text { tons } \\
23.20 \text { tons } \\
0.306 \text { tons }\end{array}$ \\
\hline $\begin{array}{l}\text { Diesel fuel } \\
\text { consumption for } \\
\text { transport }\end{array}$ & 14,844 liters & $\begin{array}{l}\text { - } \mathrm{B} 171+ \\
\text { - } \mathrm{NaOH} \\
\text { - } \mathrm{H}_{2} \mathrm{SO}_{4} \\
\end{array}$ & $\begin{array}{l}0.191 \text { tons } \\
0.23618 \text { tons } \\
0.00591 \text { tons } \\
\end{array}$ \\
\hline Total area & $203.3 \mathrm{Ha}$ & Truck ritation for $\mathrm{CPO}$ & 840 \\
\hline FFB yield & $26,067.84$ tons & Produksi CPO & $5,020.60$ tons \\
\hline Distance to mill & $20 \mathrm{~km}$ & Distance to CPO Storage & $250 \mathrm{~km}$ \\
\hline Truck load per ritation & 4.92 tons & CPO truck ritation per year & 840 \\
\hline Truck ritation per year & 1,003 & CPO truck loading per ritation & 23.99 ton \\
\hline \multirow[t]{2}{*}{ Transport emission } & \multirow{2}{*}{$\begin{array}{l}9.44 \mathrm{kgCO}_{2} \\
\text { per ton FFB }\end{array}$} & POME & 57,554 ton \\
\hline & & Steam Input & $146,333,773 \mathrm{MJ}$ \\
\hline \multirow{4}{*}{$\begin{array}{l}\text { Emission } \\
\text { 1. Air } \\
-\mathrm{Nitrogen} \\
-\mathrm{K}_{2} \mathrm{O} \\
-\mathrm{CO}_{2} \text { from herbicide } \\
-\mathrm{CO}_{2} \text { from diesel use } \\
\text { 2. } \mathrm{Soil} \\
-\mathrm{N}_{2} \mathrm{O}\end{array}$} & \multirow[b]{3}{*}{$\begin{array}{l}2,740.68 \mathrm{~kg} \\
56,823 \mathrm{~kg} \\
4,616.05 \mathrm{~kg} \\
70,331 \mathrm{~kg}\end{array}$} & BOD Raw Effluent & $1,408 \mathrm{ppm}$ \\
\hline & & COD influent & $5,513 \mathrm{ppm}$ \\
\hline & & 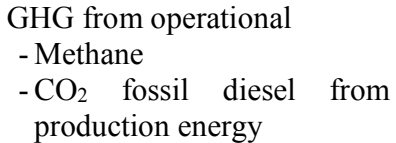 & $\begin{array}{l}575,540 \mathrm{~kg} \\
20,526,541.4 \mathrm{~kg}\end{array}$ \\
\hline & $953,283 \mathrm{~kg}$ & $\begin{array}{l}-\mathrm{CO}_{2} \text { from chemical agent } \\
\text { usage }\end{array}$ & $36166.8 \mathrm{~kg}$ \\
\hline
\end{tabular}

Source : PT XYZ, 2016

\subsection{Life-Cycle Impact Assessment}

\subsubsection{Characterization}

Characterization is an assessment of the magnitude of the substance that contributes to the impact category. In each category the impacts have different units because they are related to different damages. For example, Disability Adjusted Life Years (DALY) is for human health; Potential Affected Fraction $\left(\mathrm{PAF}^{*} \mathrm{~m}^{2} \mathrm{yr}\right)$ and Potentially Disappeared Fraction $\left(\mathrm{PDF}^{*} \mathrm{~m}^{2} \mathrm{yr}\right)$ are for ecosystem quality, and MJ Surplus is for resources.

The activities in the oil palm estate in 2015 had the largest impact on the climate change (0.00229 DALY) and the smallest impact on the ozone layer (9,33E-10 DALY). Moreover the land use impact also had the largest value among the ecosystem qualities (89.9 $\mathrm{PDF}^{*} \mathrm{~m}^{2} \mathrm{yr}$ ). Similarly, in the palm oil mill, the largest impact was on the climate change (0.0103 DALY). However, the ecotoxicity in the mill $\left(621 \mathrm{PAF}^{*} \mathrm{~m}^{2} \mathrm{yr}\right)$ was larger than the land use (395 $\left.\mathrm{PDF}^{*} \mathrm{~m}^{2} \mathrm{yr}\right)$ and acidification/eutrophication $\left(49,6 \mathrm{PDF}^{*} \mathrm{~m}^{2} \mathrm{yr}\right)$. 


\subsubsection{Normalization}

Normalization is intended to create a uniform unit for all impact categories, so that all impact categories use a same and comparable unit. In 2015, the plantation that had the most significant impact category was climate change (0.149). The second largest impact category was land use $(0.0175)$ while the third largest impact category is inorganics respiratory (0.00404). Furthermore, in the mill, the results of normalization for climate change, land use, and carcinogens were $0.672,0.077$, and 0.072 , respectively.

The result of weighting from the plantation process in 2015 shows that the largest impact category was climate change. The climate change impact was due to land conversion from forests to oil palm plantations. Furthermore, the fertilizers and herbicides usage indirectly emitted $\mathrm{N}_{2} \mathrm{O}$. It also delivered emissions to the ground. The transportation sector also brought the impact on the air, such as for plantation activities. The emission that had the largest impacts magnitude of climate change on plantation activities was $\mathrm{N}_{2} \mathrm{O}$. The fertilizers application caused the emissions; one of them was urea fertilizer. The second impact that contributed to the industrial process was land use. In the process of plantation activities, there was land use change from forest to a large palm oil plantation of 200 hectares. In 2015, the process in plantation and mill contributed to climate change category was 0.013 DALY or after normalized $202 \mathrm{Pt}$. Meanwhile, the land use category had $395 \mathrm{PDF}^{*} \mathrm{~m}^{2} \mathrm{yr}$ or $30.8 \mathrm{Pt}$.

\subsubsection{Single Score}

Single Score aims to classify impact categories that have been weighted based on the activity or process that contributes to the impact. It can be inferred that the process of Fresh Fruit Bunch or activities in the plantation has the largest impacts, such as landuse, acidification/eutrophication, climate change, respiratory inorganics, carcinogens, and fossil fuel depletion. The cause of the high impact of climate change was the emission value of $\mathrm{N}_{2} \mathrm{O}$ emitted indirectly from the fertilizers usage using chemical fertilizers. $\mathrm{N}_{2} \mathrm{O}$ emissions might also come from palm oil mill, i.e. the use of inputs derived from chemicals during the production process. In 2015, $\mathrm{N}_{2} \mathrm{O}$ emission was as much as $215 \mathrm{Pt}$. Apart from the $\mathrm{N}_{2} \mathrm{O}$ emissions, the impacts of climate change can also be affected by POME. POME actually has the potential to produce biogas such as methane gas $\left(\mathrm{CH}_{4}\right)$ but it also generates $\mathrm{CO}_{2}$ emissions. In 2015, $\mathrm{CH}_{4}$ emissions was $2.42 \mathrm{Pt}$. $\mathrm{CO}_{2}$ emissions also arose from the use of chemicals and from transportation sector in the mill. It is expected that the biogas can potentially be utilized as a renewable energy source as well as to reduce the rising environmental impacts.

\subsection{Comparison to other studies}

Compared to the study conducted by Hansen [2], who examined the life-cycle assessment (LCA) on the production of crude palm oil in Malaysia, there are some differences in the magnitude of environmental impacts. The impacts that were largest than 1.0 were on the fossil fuel depletion (19.5 Pt at the activities at the plantation), respiration inorganics (10.9 $\mathrm{Pt}$ at the plantation and $13.9 \mathrm{Pt}$ at the Mill), climate change (2.7 $\mathrm{Pt}$ at the plantation), and acidification/eutrophication (1.8 Pt at the plantation). The system boundary applied by Hansen's research began with plantation (nursery and harvesting), industry, and disposal processes. Their research used SimaPro v 5 LCA software and impact method of Ecoindicator 99 [2]. Functional unit (FU) had been adjusted to the production of $1000 \mathrm{~kg} \mathrm{CPO}$ (output of $5000 \mathrm{~kg}$ FFB) in Malaysia. The differences could be due to the land use change, yield of FFB, and the fertilizer production. It can be seen that climate change impacts in Mill $\mathbf{J}$ are much larger than those in Malaysia according Hansen's study. In other study in 
Malaysia, Wicke et al. [6] assumed that FFB yield at their case plantation study was 25 ton FFB per hectare per year. Both of these studies [2 and 6] have relatively large impact on respiratory inorganics due to chemicals utilization.

Meanwhile, Sampattagul et al. [7] studied the life-cycle assessment of palm oil biodiesel in Thailand that had a system boundary starting from the plantation process, biodiesel production, and utilization of biodiesel. SimaPro software was used in their research but the method used to calculate the impact was the Environmental Design of Industrial Products (EDIP) [7]. The comparison between Sampattagul et.al's study [7] and the current research is discussed more deeply in regarding the impact of plantation activities, because in Sampattagul et al.'s study did not calculate the impact that generated in the processing of palm oil. The impact of the activities at the plantation in Thailand showed $1.03 \times 10^{-4} \mathrm{Pt}$. The greatest impact was the release of toxic substances into the air, water, and soil; radioactive waste; and global warming. Radioactive waste was generated from chemical production, such as pesticides, glyphosate, boron, and kieserite. The environmental impact are almost identical to those of Mill J, from chemical fertilization and herbicide processes.

\section{CONCLUSIONS}

In 2015, the process in plantation and mill contributed to climate change category was 0.013 DALY or $202 \mathrm{Pt}$. Meanwhile, the land use category had an impact of $395 \mathrm{PDF}^{*} \mathrm{~m}^{2} \mathrm{yr}$ or 30.8 $\mathrm{Pt}$. The cause of the high impact of climate change was the emission value of $\mathrm{N}_{2} \mathrm{O}$ derived from the existing plantation process (to produce fresh fruit bunches). The impact was generated due to chemical fertilizers application. The optimization of chemical fertilizers usage should be done as well as increasing the yield of fresh fruit bunch to improve the efficiency. Furthermore, one of the environmental impacts that can be treated based on this study is $\mathrm{CH}_{4}$ emission from palm oil mill effluent (POME). It can be processed to biogas, which is useful for energy. Otherwise, it can contribute to the greenhouse gas emission, which increase the impact of climate change. Therefore, a feasibility study of $\mathrm{CH}_{4}$ emission treatment should be conducted. Another case study in Mill P, the biogas generated from POME has been successfully produced and, hence, the surplus energy can be obtained [8].

\section{References}

1. GAPKI. Reflection of Palm Oil Industry and Its Prospect in 2016 [Internet]. Pers Conference GAPKI. 2016 [cited 2016 Apr 20]. Available from: http://www.gapki.or.id/Page/PressReleaseDetail?guid=39f6f3f2-0419-42d4-8d1b$9524871 \mathrm{~d} 3 \mathrm{cf} 2$

2. S. Hansen, Int. J. Life Cycle Assess. 12, 50-59 (2005)

3. A. Wijono, Environmental Assessment and Palm Oil Potency Mapping as a Renewable Energy Source in Indonesia (BPPT, Tangerang, 2013)

4. N. Nazir, D. Setyaningsih, 7th Biomass Asia Workshop, Jakarta (2010)

5. H. Baayen, Eco-indicator 99 Manual for Designers (Ministry of Housing, Spatial Planning and the Environment, The Netherlands, 2000)

6. B. Wicke, V. Dornburg, M. Junginger. Biomass Bioenergy 32, 1322-1337 (2008).

7. S. Sampattagul, P. Nutongkaew, T. Kiatsiriroat Int. J. Renew. Energy 6 (1), 1-14 (2011).

8. P. Andarani, W.D. Nugraha, Wieddya. AIP Conference Proceedings 1823, 020064 (2017) 